\title{
Leukotriene receptors as potential therapeutic targets
}

\author{
Takehiko Yokomizo, ${ }^{1}$ Motonao Nakamura, ${ }^{2}$ and Takao Shimizu ${ }^{3,4}$ \\ 'Department of Biochemistry, Graduate School of Medicine, Juntendo University, Tokyo, Japan. ㄹepartment of Life Science, Graduate School of Science, Okayama University of Science, Okayama, Japan. \\ ${ }^{3}$ Department of Lipidomics, Faculty of Medicine, University of Tokyo, Tokyo, Japan. ${ }^{4}$ Department of Lipid Signaling, National Center for Global Health and Medicine, Tokyo, Japan.
}

\begin{abstract}
Leukotrienes, a class of arachidonic acid-derived bioactive molecules, are known as mediators of allergic and inflammatory reactions and considered to be important drug targets. Although an inhibitor of leukotriene biosynthesis and antagonists of the cysteinyl leukotriene receptor are clinically used for bronchial asthma and allergic rhinitis, these medications were developed before the molecular identification of leukotriene receptors. Numerous studies using cloned leukotriene receptors and genetically engineered mice have unveiled new pathophysiological roles for leukotrienes. This Review covers the recent findings on leukotriene receptors to revisit them as new drug targets.
\end{abstract}

Leukotrienes (LTs) are a class of mediators derived from arachidonic acid by the initiating activity of 5-lipoxygenase and 5-lipoxygenase-activating protein (FLAP). They are involved in self-defense systems against foreign bodies or microorganisms, but overproduction causes a variety of immune and inflammatory diseases (1). Currently, while only 5-lipoxygenase inhibitors and cysteinyl leukotriene receptor $1\left(\mathrm{CysLT}_{1}\right)$ antagonists are marketed to treat bronchial asthma and allergic rhinitis, other targets for at least four distinct types of receptors or their combinations are under consideration. The 3D structure analysis followed by the determination of the catalytic sites of $\mathrm{LTC}_{4}$ synthase and LTA4 hydrolase provides new structural bases for the development of LT synthesis inhibitors (2-6). As described here, the 3D structure of $\mathrm{BLT}_{1}$ has been resolved, enhancing the rational design of potent antagonists and inverse agonists. We also refer readers to a more comprehensive review of leukotriene receptors including agonist and antagonist structures and their applications (7).

\section{Characterization of BLT receptors}

Two G protein-coupled receptors (GPCRs) have been cloned as receptors for leukotriene $B_{4}\left(\operatorname{LTB}_{4}\right)$ (Table 1 and refs. 8,9$)$. The first, $\mathrm{BLT}_{1}$, known as a high-affinity $\mathrm{LTB}_{4}$ receptor, is expressed in various subsets of leukocytes and is responsible for $\mathrm{LTB}_{4}$ dependent leukocyte migration. The second, $\mathrm{BLT}_{2}$, was originally reported as a low-affinity $\mathrm{LTB}_{4}$ receptor and is now considered as a receptor for various oxidized fatty acids, including 12-hydroxyheptadecatrienoic acid (12-HHT) and hydroxyeicosatetraenoic

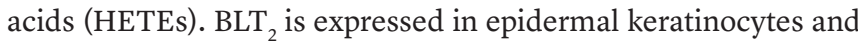
epithelial cells of intestine, cornea, and lung and is responsible for wound healing and epidermal barrier function. In addition to other Reviews in this series, the reader may also refer to a comprehensive series of 9 recent reviews on $\mathrm{LTB}_{4}(10-18)$.

$B L T_{1}$. Human BLT 1 consists of 352 amino acids and is mainly expressed in various subsets of leukocytes, including granulocytes (8), eosinophils $(19,20)$, and effector-type CD4 $4^{+}$and $C D 8^{+}$

Conflict of interest: The authors have declared that no conflict of interest exists. Reference information: / Clin Invest. 2018;128(7):2691-2701.

https://doi.org/10.1172/JCI97946.
T cells (21-23), as well as certain subsets of dendritic cells (24, 25) and macrophages (26). BLT 1 is also expressed in murine (27) and human (28) vascular smooth muscle cells, and is involved in atherogenesis and vascular injury. It is a high-affinity and $\mathrm{LTB}_{4}-$ specific receptor with a $K_{\mathrm{D}}$ value of $0.15 \mathrm{nM}$ for $\mathrm{LTB}_{4}$ when

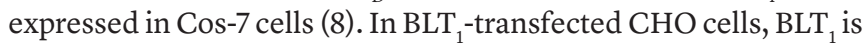
able to couple with both $\mathrm{G}_{\mathrm{i}}$-like and $\mathrm{G}_{\mathrm{q}}$-like (G16) $\mathrm{G}$ proteins, and an extensive mutagenesis study showed that intracellular loop 3 is important for the $\mathrm{G}_{\mathrm{i}}$ coupling of $\mathrm{BLT}_{1}$ (29). Human BLT 1 has two $\mathrm{N}$-glycosylation sites (N2 and N164), and mutagenesis of these asparagine residues does not affect localization, ligand binding, or intracellular signaling of $\mathrm{BLT}_{1}$. BLT 1 does not contain the cysteine residue that is often palmitoylated in the $\mathrm{C}$-tails of various GPCRs; instead, it has a so-called helix 8 structure immediately following transmembrane 7. Helix 8 of BLT $_{1}$ is important in the conformational change to the low-affinity state after $G$ protein activation $(30,31)$ and internalization $(32-34)$ of BLT $_{1}$.

Recently, the crystal structure analysis of BLT $_{1}$ with the antagonist BIIL260 was achieved (Figure 1, A and B, and ref. 35). Docking study with $\mathrm{LTB}_{4}$ and BLT indicates that $\mathrm{LTB}_{4}$ would interact with the residues H96, R158, E187, and S243 that were predicted to be involved with $\mathrm{LTB}_{4}$ binding by the mutation study (Figure $1 \mathrm{C}$ and ref. 36). The benzamidine moiety of BIIL260 interacted with the side chains of D66, V69, S106, W236, and S276, which are shared among most GPCRs (Figure 1B). These amino acid residues bind water molecules as the sodium ion-centered water

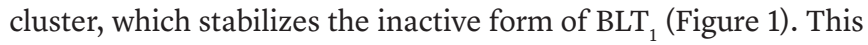
observation suggests the possible application of the benzamidine moiety as a common structural feature of inverse agonists for various GPCRs, including BLT . $_{1}$

The most important characteristic of $\mathrm{LTB}_{4}$ is its potent chemo-

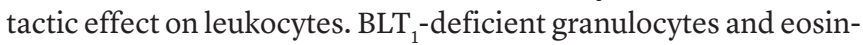
ophils do not migrate toward $\operatorname{LTB}_{4}(19-23,37)$. BLT 1 stimulation in leukocytes leads to degranulation through the production of phosphatidylinositol tris-phosphates $\left(\mathrm{IP}_{3}\right)$ via activation of phosphatidylinositol-3-kinase (PI3 kinase) (38). LTB 4 also activates phagocytosis in macrophages through the activation of $\mathrm{G}_{\mathrm{i}}$, PI3 kinase, Rac, and Syk (38). Recently, the receptor for advanced glycation end products (RAGE) was identified as a $\mathrm{BLT}_{1}$-binding protein 
Table 1. Characteristics of leukotriene receptors

\begin{tabular}{|c|c|c|c|c|}
\hline & $\mathrm{BLT}_{1}$ & $\mathrm{BLT}_{2}$ & CysLT $_{1}$ & CysLT $_{2}$ \\
\hline Ligand & $\mathrm{LTB}_{4}>20-\mathrm{OH}-\mathrm{LTB}_{4}$ & $\begin{array}{c}\text { 12-HHT }>\text { LTB }_{4}>12(\mathrm{~S}) \text {-HETE }> \\
12(\mathrm{R})-\mathrm{HETE}>15(\mathrm{~S})-\text { HETE }\end{array}$ & $\mathrm{LTD}_{4}>\mathrm{LTC}_{4}>>\mathrm{LTE}_{4}$ & $\mathrm{LTD}_{4}=\mathrm{LTC}_{4} \gg>\mathrm{LTE}_{4}$ \\
\hline Antagonist & $\begin{array}{c}\text { BIIL260, LY255283, ZK158252, } \\
\text { CP195543, U75302 (weak agonist) }\end{array}$ & LY255283, ZK158252, CP195543 & $\begin{array}{l}\text { Montelukast, zafirlukast, } \\
\text { pranlukast, MK-571, pobilukast }\end{array}$ & $\begin{array}{c}\text { Zafirlukast, pranlukast, BAY-u9773, } \\
\text { gemilukast }\end{array}$ \\
\hline Expression (human) & $\begin{array}{l}\text { Leukocytes > spleen, } \\
\text { smooth muscle, lung, intestine }\end{array}$ & Intestine, skin > endothelial cells & $\begin{array}{l}\text { Leukocytes, spleen, } \\
\text { smooth muscle > lung, intestine }\end{array}$ & $\begin{array}{l}\text { Leukocytes, spleen, adrenal medulla, } \\
\text { lung, heart, brain }\end{array}$ \\
\hline
\end{tabular}

that regulates $\mathrm{BLT}_{1}$ signaling (39). RAGE functions as a molecular switch for $\mathrm{BLT}_{1}$, inhibits $\mathrm{BLT}_{1}$-dependent NF- $\kappa \mathrm{B}$ activation, and stimulates $\mathrm{BLT}_{1}$-dependent chemotaxis. RAGE was also shown to bind to GPCRs other than BLT 1 and is a new class of GPCR modulator and a new target of GPCR study (40).

$B L T_{2}$. During the analysis of leukocyte-specific transcription of $\mathrm{BLT}_{1}(41)$, we and others identified a putative open reading frame for a GPCR with similarity to $\mathrm{BLT}_{1}(9,42-44)$. As the membrane fraction of cells overexpressing this receptor exhibited a low-affinity $\mathrm{LTB}_{4}$ binding with $K_{\mathrm{D}}$ values of 10-20 nM, this receptor was named $\mathrm{BLT}_{2}$. $\mathrm{BLT}_{2}$ shares amino acid identity of $45 \%$ with $\mathrm{BLT}_{1}$ and high interspecies homology. In contrast to $\mathrm{BLT}_{1}, \mathrm{BLT}_{2}$ is a promiscuous receptor that can be activated by 12(S)-HETE, 12(S)-HPETE, and 15(S)-HETE at micromolar concentrations (45). In 2008, we identified $\mathrm{BLT}_{2}$-specific agonistic activity in lipid extract of rat small intestine, then partially purified and determined the structure of this BLT $_{2}$ agonist as 12(S)-hydroxyheptadecatrienoic acid (12-HHT) (46). Prior to our work, 12-HHT had been known as a nonenzymatic degradation product of prostaglandin endoperoxides or an equimolar byproduct of thromboxane biosynthesis from prostaglandin $\mathrm{H}_{2}\left(\mathrm{PGH}_{2}\right)$, a process that includes removal of three carbons to produce malondialdehyde (47-49). No biological activity of 12-HHT had been reported.

Platelets produce a large amount of $12-\mathrm{HHT}$ in thromboxane $A_{2}$ synthase-dependent and -independent pathways, and aspirin and other NSAIDs inhibit 12-HHT production (50). We found that $12-\mathrm{HHT}$ activates $\mathrm{BLT}_{2}$ at lower concentrations than $\mathrm{LTB}_{4}$, leading to the activation of $\mathrm{G}_{\mathrm{i}}$ - and $\mathrm{G}_{\mathrm{q}}$-type $\mathrm{G}$ proteins. In some cancer cells, $\mathrm{BLT}_{2}$ was shown to activate the generation of reactive oxygen species (51). Most classical BLT antagonists inhibit both $\mathrm{BLT}_{1}$ and $\mathrm{BLT}_{2}$, and a synthetic $\mathrm{BLT}_{2}$-specific agonist (CAY10583) is available (52-54). In contrast to $\mathrm{BLT}_{1}$ expression in leukocytes, $\mathrm{BLT}_{2}$ is expressed in keratinocytes (53), epithelial cells of intestine (55) and cornea (54), lung alveolar type 2 cells, and vascular endothelial cells (56).

\section{$\mathrm{BLT}_{1}$ in disease}

Even before its molecular identification, BLT $_{1}$ had been considered as an important drug target, especially for inflammatory diseases $(7,57)$. Here we describe representative reports on animal disease models using $\mathrm{BLT}_{1}$-knockout $\left(\mathrm{BLT}_{1}-\mathrm{KO}\right)$ mice and $\mathrm{BLT}_{1}$ antagonists.

Chemotaxis of leukocytes. Two groups independently reported attenuated leukocyte chemotaxis in the BLT $-\mathrm{KO}$ mouse using peritonitis models $(19,20)$. The effect of BLT $_{1}$ deficiency was more prominent in eosinophils than in granulocytes. The importance of $\mathrm{BLT}_{1}$ in eosinophils was later confirmed by nematode infection experiments in which BLT -deficient eosinophils did not accumulate and kill nematodes (58). Although classical studies showed the restricted expression of BLT $_{1}$ in granulocytes, eosinophils, and macrophages, recent studies showed that $\mathrm{BLT}_{1}$ expression is observed more widely in a variety of subsets of leukocytes, as follows. BLT ${ }_{1}$ is not expressed in naive T cells but is strongly induced by $\mathrm{T}$ cell differentiation: both $\mathrm{CD} 4^{+}$and $\mathrm{CD} 8^{+}$effector-type $\mathrm{T}$ cells abundantly express BLT $_{1}$ and migrate to inflamed tissues (21-23). Interestingly, $\mathrm{LTB}_{4}$ was shown to inhibit the differentiation of regulatory $\mathrm{T}$ cells and to stimulate naive $\mathrm{T}$ cell differentiation into Th17 cells in vitro (59). Monoclonal antibodies against human (60) and mouse (61) BLT 1 have been established and will help to analyze the detailed expression pattern of BLT $_{1}$ in these species.

Allergic airway inflammation. The importance of $\mathrm{BLT}_{1}$ in allergic airway inflammation was confirmed by murine models of bronchial asthma in which ovalbumin (OVA) was used for sensitization and challenge. Infiltration of $\mathrm{CD}^{+}$and $\mathrm{CD} 8^{+} \mathrm{T}$ cells into the airway after OVA challenge was greatly reduced in $\mathrm{BLT}_{1}-\mathrm{KO}$ mice (23). In addition to $\mathrm{T}$ cells, eosinophil infiltration was attenuated in $\mathrm{BLT}_{1}-\mathrm{KO}$ mice with reduced production of $\mathrm{Th} 2$ cytokines and attenuated airway hyperresponsiveness (AHR) to methacholine (37). Miyahara et al. showed that IL-13-producing $\mathrm{CD}^{+}$and $\mathrm{CD}^{+} \mathrm{T}$ cells were reduced in allergic $\mathrm{BLT}_{1}-\mathrm{KO}$ lung, and transfer of OVA-sensitized $\mathrm{BLT}_{1}^{+/+} \mathrm{T}$ cells fully restored the reduced AHR in BLT $-\mathrm{KO}$ mice, showing the importance of IL-13-producing $\mathrm{T}$ cells in AHR (62). They also showed that effector-type $\mathrm{CD} 8^{+} \mathrm{T}$ cells express a higher level of $\mathrm{BLT}_{1}$, and $\mathrm{LTB}_{4}$-dependent trafficking of $\mathrm{CD}^{+}$effector $\mathrm{T}$ cells is important in establishing AHR in mice (63). Dendritic cells also express $\operatorname{BLT}_{1}(24,25)$, and adoptive transfer experiments using OVA-loaded dendritic cells showed that $\mathrm{BLT}_{1}$ expression in antigen-loaded dendritic cells is crucial in inducing asthmatic response (24).

Inflammatory arthritis. The roles of the $\mathrm{LTB}_{4} / \mathrm{BLT}_{1}$ axis in inflammatory arthritis have been studied using several animal models. In the $\mathrm{K} / \mathrm{BxN}$ serum transfer arthritis model, in which serum transferred from arthritic transgenic mice produces robust arthritis in WT strains, genetic or pharmacological ablation of $\mathrm{BLT}_{1}$ abrogated the development of arthritis, showing the requirement for $\mathrm{BLT}_{1}$ in recruiting neutrophils into the joints (64). Although $\mathrm{BLT}_{1}$ was initially shown to be important in the early phase of the disease, it is required for the continuous extravasation of neutrophils throughout the course of an arthritis model (65). Mice deficient in 5-lipoxygenase were also tested using the same model: in that study, 5-lipoxygenase but not LTC $_{4}$ synthase 
A

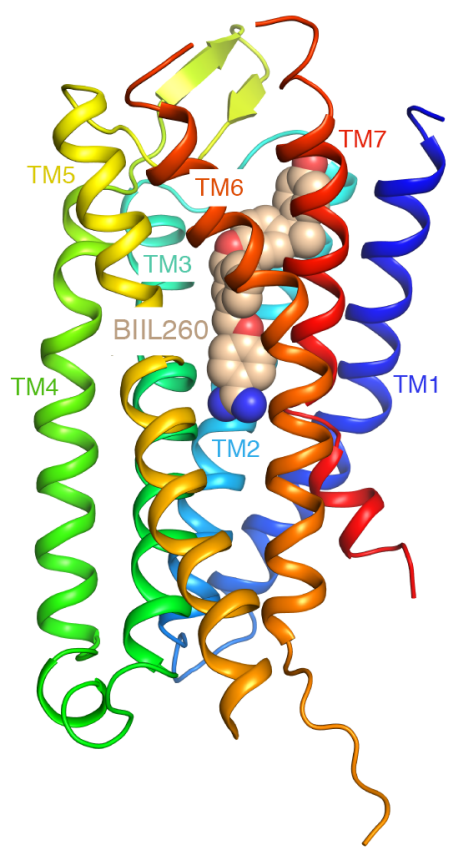

B

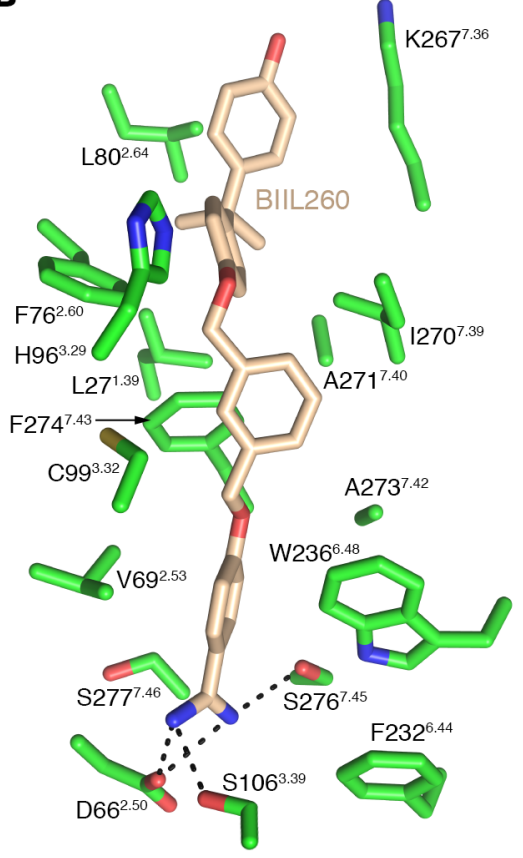

C

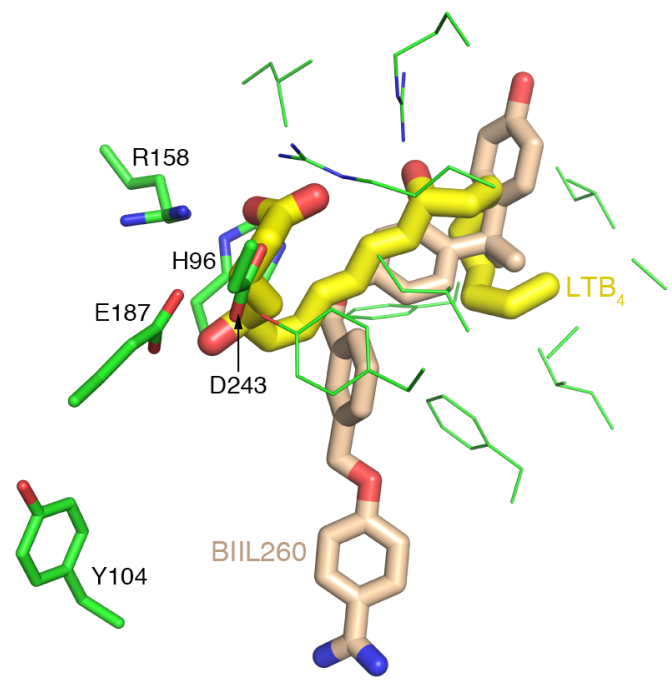

Figure 1. Structure of guinea pig BLT, bound with a BLT antagonist, BIIL260. (A) Overall structure of BLT, and BIIL260 complex (35). BLT, is presented as a rainbow-colored cartoon model, and BIIL260 is presented as pink (carbon), blue (nitrogen), and red (oxygen) spheres. (B) Mode of BIIL260 binding by BLT. BLT, side chains within 4 Å from BIIL260 are presented by stick models. Carbon and sulfur atoms of BLT, are colored green and gold, respectively. The salt bridge and hydrogen bond interactions are indicated by black dashed lines. (C) Docking of LTB $_{4}$ in the orthosteric binding site of BLT. The docking study was performed with the program AutoDock 4 (184). Carbon atoms of $\mathrm{LTB}_{4}$ are colored yellow. The residues involved in the LTB 4 binding shown by the mutation study (36) are presented by stick models.

proved requisite for the development of arthritis (66). $\mathrm{BLT}_{1}-\mathrm{KO}$ mice were also tested in a collagen-induced arthritis (CIA) model. BLT 1 -KO and $\mathrm{BLT}_{1} / \mathrm{BLT}_{2}$ double-KO mice were completely protected from CIA, despite normal accumulation of serum anticollagen antibody $(67)$. BLT 1 antagonists $(66,68)$ were also effective for the attenuation of arthritis.

Atherosclerosis. The relationship between $\mathrm{LTB}_{4}$ and atherosclerosis has been documented in several reports. LTB $_{4}$ triggered adhesion of human monocytes to endothelial cells in a $\beta_{1}$ and $\beta_{2}$ integrin-dependent fashion (69), and strongly increased monocyte chemoattractant protein-1 (MCP-1) (70). In $\mathrm{LDLr}^{-/}$and apoE-/mice, the BLT antagonist CP-105,696 reduced atherogenesis without affecting the plasma lipid concentrations (71). Atherogenesis was attenuated in $\mathrm{BLT}_{1}-\mathrm{KO}$ mice crossed with $\mathrm{apoE}^{-/-}$mice, which was explained by the lack of $\mathrm{LTB}_{4}$-dependent expression of CD36 (a fatty acid translocase, B-type scavenger receptor) and CCL2 chemokine (72), and by the reduced recruitment of smooth muscle cells to the atherosclerotic lesions (27).

Cancer. Although the involvement of eicosanoids, especially $\mathrm{PGE}_{2}$, in carcinogenesis has been extensively studied (73), the contribution of $\mathrm{LTB}_{4}$ to cancer has not been well demonstrated. Recently, inflammation has been considered as an important factor in the initiation and progression of certain cancers, and some research has focused on the roles of $\mathrm{LTB}_{4}$ and $\mathrm{BLT}_{1}$ in cancer (17). Infection of endothelial cells with Kaposi's sarcoma-associated herpesvirus induced higher expression of 5-LOX, FLAP, and LTA4H, and increased $\mathrm{LTB}_{4}$ production (74). Hypoxic ovarian cancer cells express higher levels of $\mathrm{LTB}_{4}$-biosynthetic enzymes, and produced a larger amount of $\mathrm{LTB}_{4}$, leading to the recruitment of tumor-associated macrophages (75). A 5-LOX inhibitor, zileuton, was shown to inhibit polyp formation in the $\mathrm{APC}^{\mathrm{d} 468}$ mouse colon (76) and the growth of ovarian cancer xenografts (75), possibly by inhibiting local inflammation. Recently, Jala et al. reported that $\mathrm{BLT}_{1}$ deficiency in $\mathrm{Apc}^{\mathrm{Min} /+}$ mice resulted in increased size and number of intestinal tumors due to altered gut microbiota and increased chronic inflammation (77). Thus, depending on the context and experimental conditions, the $\mathrm{LTB}_{4} / \mathrm{BLT}_{1}$ axis acts as either a tumor-promoting or a tumor-suppressing factor.

Clinical studies on BLT -targeted therapy. Several $\mathrm{BLT}_{1}$ antagonists were tested in a few inflammatory diseases. Oral administration of a BLT 1 antagonist, LY293111, attenuated LTB -dependent activation of Mac-1 in human neutrophils (78) and skin (79), but failed to decrease allergic inflammation induced by histamine and allergen challenges (80). Psoriasis was also a target of BLT ${ }_{1}$ antagonists, as recently shown in a mouse experiment (81); however, LY293111 was not effective on stable plaques (82), nor on relapse in human psoriasis (83). LY293111 was also tested in cystic fibrosis (84) and chondrosarcoma and melanoma $(85,86)$ without significant effectiveness.

\section{$\mathrm{BLT}_{2}$ in health and disease}

Identification of $\mathrm{BLT}_{2}$ was reported in 2000 (9), and the first report on $\mathrm{BLT}_{2}$-KO mice appeared in 2010 (55). In some cases, it is difficult to distinguish the roles of $\mathrm{BLT}_{1}$ and $\mathrm{BLT}_{2}$, because both receptors are activated by $\mathrm{LTB}_{4}$, transduce similar intracellular signaling, and are antagonized by most BLT antagonists; however, different tissue distribution gives a clue to distinguish biological 


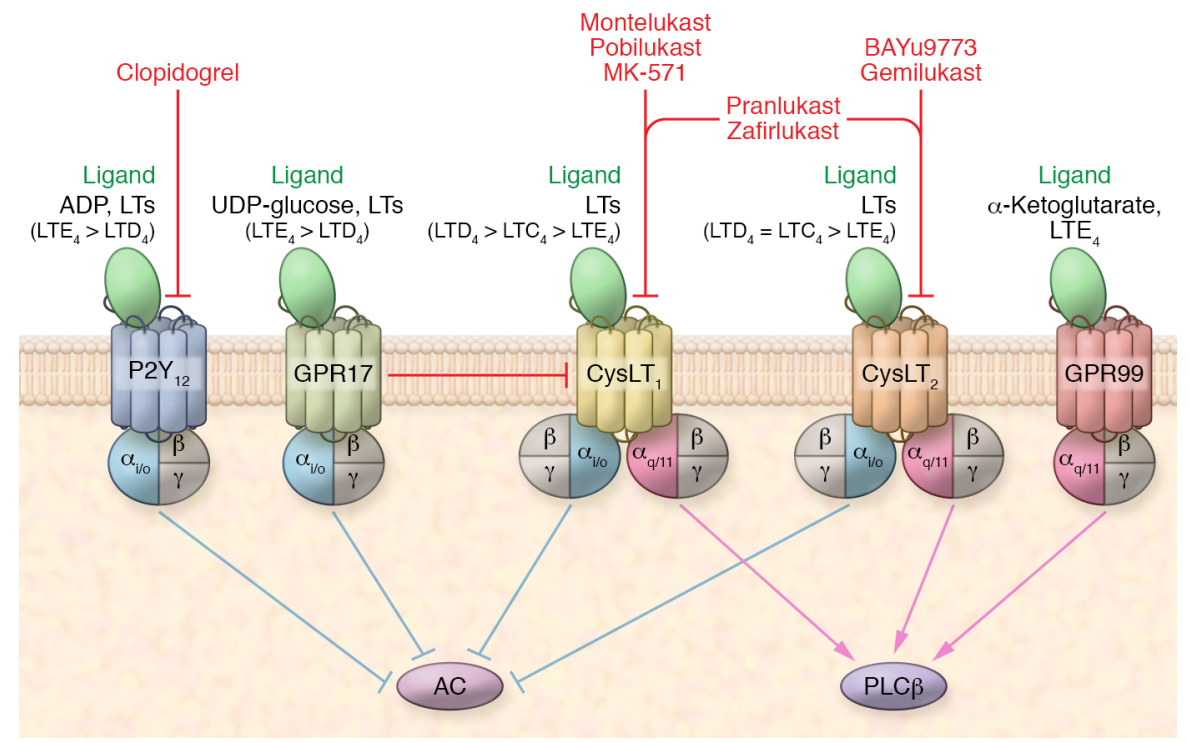

Figure 2. Signaling via CysLT, , CysLT $_{2}$, GPR17, GPR99, and P2Y $\mathbf{1 2}_{12}$. Synthetic antagonists for each receptor are given in red text. Ligands and relative affinities are described adjacent to their respective receptor. GPR17 is a negative regulator

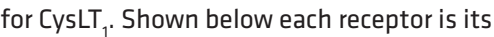
downstream coupling to $G_{i / 0}$ and adenylyl cyclase $(A C)$ and/or $G_{q / 11}$ and phospholipase $C \beta(P L C \beta)$.

roles of these two receptors. Currently, $\mathrm{BLT}_{2}$ agonists are attracting interest as new drugs for skin, corneal, and intestinal ulcers.

Small intestine. The first phenotype of $\mathrm{BLT}_{2}$-deficient mice was susceptibility to drug-induced inflammatory colitis. Because of the lack of $\mathrm{BLT}_{2}$-specific antibody at that time, in situ hybridization was used to show $\mathrm{BLT}_{2}$ expression in epithelial and cryptic cells of mouse intestine. $\mathrm{BLT}_{2}-\mathrm{KO}$ mice exhibited bloody stool and severe body weight loss following administration of $1 \%$ dextran sodium sulfate in the drinking water under conditions in which WT mice did not show any clinical manifestations. Histological examination showed severe intestinal inflammation in the $\mathrm{BLT}_{2}-$ $\mathrm{KO}$ intestine that may be linked to observations of increased

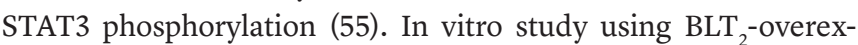
pressing Madin-Darby canine kidney II (MDCKII) cells showed that $\mathrm{BLT}_{2}$ expression increased transepithelial electrical resistance and decreased FITC-dextran leakage through MDCKII monolayers, suggesting the barrier-enhancing activity of $\mathrm{BLT}_{2}$ (55). The intracellular mechanism of $\mathrm{BLT}_{2}$-dependent barrier function will be described in the next section.

Skin and cornea. In skin, BLT $_{2}$ expression is restricted to dermal keratinocytes. Wound-healing assays after skin punching were performed using $\mathrm{BLT}_{2}-\mathrm{KO}$ mice. Mass spectrometric analysis showed the accumulation of $12-\mathrm{HHT}$ in the wound exudates, and pretreating the mice with high-dose aspirin completely abolished the accumulation of 12-HHT. Both $\mathrm{BLT}_{2}$ deficiency and aspirin treatment delayed skin wound healing with the attenuated re-epithelialization, and the aspirin effect was not seen in $\mathrm{BLT}_{2}-\mathrm{KO}$ mice. Thus, $\mathrm{BLT}_{2}$ stimulates keratinocyte migration after skin injury, and $\mathrm{BLT}_{2}$ agonists might be a therapeutic tool for intractable skin ulcers $(53$, 87). It is of note that aspirin-dependent delays in wound healing occur as a consequence of decreased production of 12-HHT but not of prostaglandins. Similarly, BLT ${ }_{2}$ is expressed in corneal epithelial cells and stimulates corneal wound healing (54). BLT 2 -KO mice also showed enhanced transepidermal water loss and antigen uptake, suggestive of attenuated skin barrier function in $\mathrm{BLT}_{2}-\mathrm{KO}$ mice. $\mathrm{BLT}_{2}$-dependent barrier function involves the enhanced expression of the tight junctional protein claudin- 4 downstream of $\mathrm{BLT}_{2}(88)$.
Lung. Small but significant $\mathrm{BLT}_{2}$ expression was observed in mouse lung, and $\mathrm{BLT}_{2}-\mathrm{KO}$ mice were evaluated in the pneumolysindependent (PLY-dependent) acute lung injury model. BLT $-\mathrm{KO}$ mice and NSAID-treated mice were sensitive to intratracheal infusion of PLY and died immediately as a result of the increased vascular permeability and subsequent pulmonary edema. PLY treatment induced the production of CysLTs in the lung, and the CysLT $_{1}$ antagonist montelukast prevented the death of $\mathrm{BLT}_{2}-\mathrm{KO}$ and NSAID-treated mice, suggesting the possible drug repositioning of CysLT 1 antagonists for acute lung injury (56). BLT - -KO mice showed a severe eosinophilic lung inflammation in an OVA-induced allergic airway disease model. This was explained by the enhanced production of IL-13 from $\mathrm{BLT}_{2}$-deficient $\mathrm{CD}^{+}{ }^{+} \mathrm{T}$ cells (89).

\section{Characterization of CysLT receptors}

So far, five CysLT receptors have been identified: CysLT 1 , CysLT 2 , $\mathrm{P}_{12} \mathrm{Y}_{12}, \mathrm{GPR} 99$, and GPR17 (Figure 2 and Table 1). CysLT 1 is widely expressed in spleen, leukocytes, lung, small intestine, colon, and skeletal muscle (90-92). CysLT 2 exhibits $37.3 \%$ amino acid identity with CysLT $_{1}$ (93), and is exclusively expressed in heart, adrenals, leukocytes, spleen, lymph nodes, and brain (93-96). CysLT $_{1}$ is preferentially activated by $\mathrm{LTD}_{4}$, whereas CysLT 2 binds both $\mathrm{LTC}_{4}$ and $\mathrm{LTD}_{4}$ with equal affinity. Recently, P2Y ${ }_{12}$, GPR99, and GPR17 were reported as receptors for LTE $_{4}$ (97-99). Moreover, GPR17 has been proposed as a putative negative regulator of CysLT $_{1}$. This section serves to give information on these receptors.

CysLT $T_{1}$. Consistent with the clinical effectiveness of CysLT antagonists in asthma, CysLT 1 is expressed in a variety of inflammatory cells, i.e., neutrophils, mast cells, and monocytes/macrophages $(100,101)$. Human CysLT $_{1}$-expressing cells respond selectively to CysLTs with rank order of potency $\mathrm{LTD}_{4}>\mathrm{LTC}_{4}>$ $\operatorname{LTE}_{4}(90,91)$. Antagonist affinities are similar to those investigated in other functional assays for CysLT ${ }_{1}$ as well as in binding experiments $(90,102)$. Activation of CysLT 1 by $\mathrm{LTD}_{4}$ results in the production of several second intracellular messengers through phospholipase C $\beta$ (103, 104). Several reports demonstrated that CysLTs elicit $\mathrm{Ca}^{2+}$ responses via a pertussis toxin-sensitive 
(PTX-sensitive) G protein $\left(\mathrm{G}_{\mathrm{i} / \mathrm{o}}\right)$ in peripheral blood mononuclear cells $(105,106)$, or through two distinct $G$ proteins, PTX-sensitive and -insensitive $\left(\mathrm{G}_{\mathrm{q} / 11}\right)$, in monocyte/macrophage U937 cells (Figure 2 and ref. 107) as well as a human epithelial cell line, suggest-

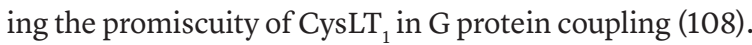

$\operatorname{CysLT}_{2}$. Comparison of human $\mathrm{CysLT}_{1}$ and $\mathrm{CysLT}_{2}$ revealed

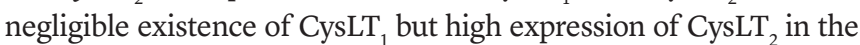
heart and eosinophils (109). In contrast, both receptors are highly expressed in spleen (93-95). In situ hybridization analyses of human lung demonstrated that CysLT $_{2}$ is expressed in interstitial macrophages and smooth muscle cells (93). Moreover, the presence of human CysLT ${ }_{2}$ mRNA was determined in atrium, ventricle, and intermediate coronary arteries by in situ hybridization (110). The potency ranking for the competition with tritiated $\left[{ }^{3} \mathrm{H}\right] \mathrm{LTD}_{4}$ binding to human CysLT is $\mathrm{LTD}_{4}=\mathrm{LTC}_{4}>\mathrm{LTE}_{4}$ (93). The CysLT antagonists are either weak (zafirlukast and pranlukast) or inactive (montelukast and pobilukast) at competing for $\left[{ }^{3} \mathrm{H}\right] \mathrm{LTD}_{4}$ binding to human CysLT 2 (Figure 2 and refs. 93, 111, 112), whereas full competition was observed with the dual $\mathrm{CysLT}_{1} / \mathrm{CysLT}_{2}$ antagonist BAY-u9773 (112). LTC $_{4}$ and LTD $_{4}$ evoke a dose-dependent activation of $\mathrm{Ca}^{2+}$ flux through a PTX-insensitive $\mathrm{G}$ protein $\left(\mathrm{G}_{\mathrm{q} / 11}\right)$ in human CysLT $_{2}$-expressing oocytes (Figure 2 and ref. 93). On the other hand, in human mast cells, the CysLT 2 stimulation elicits IL-8 secretion, and the effect is completely blocked by PTX, suggesting it occurs via $G_{i / o}$ protein (113). Recent reports demonstrated that CysLT 2 negatively regulates the development of Th2 pulmonary inflammation by inhibiting the CysLT functions on dendritic cells (114). Furthermore, $\mathrm{LTC}_{4}$, but not $\mathrm{LTD}_{4}$ and $\mathrm{LTE}_{4}$, activates mouse platelets via CysLT $_{2}$, although these cells express both CysLT and CysLT $_{2}$ (115).

Other receptors related to CysLTs. Some of $\mathrm{LTE}_{4}$-mediated responses are resistant in mice deficient in CysLT ${ }_{1}$ and $\mathrm{CysLT}_{2}$, implying the existence of $\mathrm{LTE}_{4}$ receptors. Based on the similarity among CysLT ${ }_{1}, \mathrm{CysLT}_{2}$, and the nucleotide P2Y receptors, $\mathrm{LTE}_{4}$ receptors seemed to be P2Y-like GPCRs.

Human mast cells express $\mathrm{P}_{2} \mathrm{Y}_{12}$, an adenosine diphosphate receptor, and knockdown of this receptor impaired the $\mathrm{LTE}_{4}$-elicited production of MIP- $1 \beta$ and PGD $_{2}$ in LAD2 human mast cells without altering their responses to $\mathrm{LTD}_{4}(116)$. $\mathrm{LTE}_{4}$ induces the activation of ERK1/2 in CHO cells expressing $\mathrm{P}_{2} \mathrm{Y}_{12}$, which is sensitive to PTX (Figure 2 and ref. 97). Furthermore, administration of LTE $_{4}$ to the airways of sensitized BALB/c mice induces eosinophilia, goblet cell metaplasia, and IL-13 production in response to low-dose aerosolized OVA. These effects are intact in $\mathrm{CysLT}_{1} / \mathrm{CysLT}_{2}$-null mice but are completely blocked by administration of clopidogrel, a P2 $\mathrm{Y}_{12}$-selective antagonist. A recent study showed that clopidogrel prevents airway hyperresponsiveness and eosinophilic inflammation in a mouse model of asthma (117), suggesting a possible link between platelet activation and inflammatory responses.

GPR99, which belongs to the P2Y receptor subfamily, was initially identified as a receptor for $\alpha$-ketoglutarate (118). Because the $\alpha$-ketoglutarate-dependent inositol phosphate formation in GPR99-expressing cells is insensitive to PTX, GPR99 seems to act via a $G_{q / 11}$ pathway (Figure 2 and ref. 118). Kanaoka et al. reported that GPR99 is a high-affinity receptor for $\operatorname{LTE}_{4}$ (99). The binding study revealed a specificity of GPR99 to $\left[{ }^{3} \mathrm{H}\right] \mathrm{LTE}_{4}$ with a $K_{\mathrm{D}}$ value of $2.5 \mathrm{nM}$. GPR99 is highly expressed in kidney, placenta, trachea, salivary glands, lung, and smooth muscle (118-120), and GPR99 deficiency eliminated vascular leaks in response to CysLTs in the $\mathrm{CysLT}_{1} / \mathrm{CysLT}_{2}$-KO mice (99). GPR99, which is also expressed in respiratory epithelial cells, mediates mucin release and submucosal swelling in response to $\mathrm{LTE}_{4}$ induced by Alternaria fungi (121). GPR99-KO mice are protected from epithelial cell mucin release and swelling by Alternaria or intranasal administration of $\mathrm{LTE}_{4}$. Moreover, GPR99 regulates a baseline number of mucin-containing goblet cells. Because LTE $_{4}$ elicits airflow obstruction and lung inflammation in asthmatics, inhibition of LTE $_{4} /$ GPR99 signaling may have therapeutic benefit in asthma.

GPR17, which also belongs to the P2Y receptor family, responds to two unrelated ligands: uracil nucleotides and CysLTs (122). Activation of GPR17 leads to intracellular $\mathrm{Ca}^{2+}$ increase and inhibition of cAMP synthesis, suggesting a coupling with $\mathrm{G}_{\mathrm{i} / \mathrm{o}}$ proteins (Figure 2 and refs. 98, 122). Recent studies demonstrate that the administration of montelukast, a CysLT 1 antagonist, leads to reduced neuroinflammation, elevation of hippocampal neurogenesis, and improved learning and memory in old rats $(123,124)$. These effects are abolished by GPR17 deficiency, suggesting the involvement of this receptor in the rejuvenation of the aged brain. Maekawa et al. demonstrated that GPR17 suppresses CysLT $_{1}$-mediated signaling on the cell surface through heterodimerization, proposing CPR17 as a negative regulator for CysLT 1 (125). In vivo, they demonstrated that in IgE-dependent passive cutaneous anaphylaxis, vascular permeability is increased in GPR17-KO mice and that this response is blocked by administration of a CysLT 1 antagonist (125). Furthermore, they recently reported the negative regulation of CysLT $_{1}$ by GPR17 in both the antigen-presentation and downstream phases of allergic pulmonary inflammation, suggesting physiological evidence for its negative regulatory role (126). Further studies are necessary on the mechanism and biological output of negative regulations.

\section{CysLTs and cognate receptors in health and diseases}

CysLTs are inflammatory lipid mediators implicated in multiple diseases, including asthma, allergic rhinitis, cardiovascular disease, atopic dermatitis, and experimental autoimmune encephalitis (a model of multiple sclerosis). The identification of CysLT receptors, generation of CysLT receptor-deficient mice, and development of specific antagonists have expanded the scope of functions of these mediators in disease. In particular, signaling via these receptors is implicated in many components of these diseases, such as bronchoconstriction, increased microvascular permeability, recruitment of effector cells, mucus and cytokine secretion, and fibrosis (127-133). In this section, we discuss the functional relevance of CysLT receptors to various diseases as determined by animal experiments.

Bronchoconstriction. $\mathrm{LTC}_{4}$ and $\mathrm{LTD}_{4}$ are equipotent in guinea pig tracheal smooth muscle, while $\mathrm{LTD}_{4}$ is more effective in peripheral airways (134). For example, the potency of $\mathrm{LTD}_{4}$ in the guinea pig lung parenchymal tissues is significantly different from that observed in the tracheal preparations (135), implying the existence of distinct CysLT receptors. $\mathrm{LTE}_{4}$ elicits smooth muscle constriction in isolated guinea pig trachea in preference to $\mathrm{LTC}_{4}$ and $\mathrm{LTD}_{4}$, which required an intact epithelium (136). Moreover, patients with bronchial asthma show an increased sensitivity to LTE 4 leading to airflow obstruction (137-139). Similarly, LTE $_{4}$ elicits eosinophil 
influx in asthmatic subjects (140). Recently, Yonetomi et al. established a novel guinea pig model of asthma induced by treatment with $S$-hexyl glutathione ( $S$-hexyl GSH), an inhibitor of $\gamma$-glutamyl transpeptidase $(141,142)$. Using this model, they demonstrated that both CysLT 1 and CysLT 2 promote LTC $_{4}$ - or antigen-induced bronchoconstriction. In humans, both $\mathrm{CysLT}_{1}$ and $\mathrm{CysLT}_{2}$ are expressed in lung specimens isolated from asthmatic patients, suggesting the involvement of these receptors in antigen-induced bronchoconstriction (143). Previous study showed that montelukast, a CysLT $_{1}$ antagonist, effectively ameliorates regional air trapping due to small airway obstruction in asthma, although contribution of $\mathrm{CysLT}_{2}$ in this disease has not been fully clarified (144). Intriguingly, Sekioka et al. recently suggested that inhalation of $\mathrm{LTC}_{4}$ causes $\mathrm{CysLT}_{2}$-mediated bronchoconstriction and lung air trapping in an $S$-hexyl GSH-treated guinea pig model (145).

Recruitment of effector leukocytes. In humans, peripheral blood cells, e.g., monocytes $(93,100)$, eosinophils $(146)$, and lung macrophages $(90,93)$, all express both CysLT $_{1}$ and CysLT . The $^{2}$ expressions of these receptors are further confirmed in eosinophils, mononuclear cells, and resident mast cells in nasal biopsy tissue from humans with seasonal allergic rhinitis (100). Moreover, inhaled $\mathrm{LTC}_{4}, \mathrm{LTD}_{4}$, or $\mathrm{LTE}_{4}$ increases airway eosinophil numbers in bronchoalveolar lavage fluid (BALF) prepared from humans and guinea pigs (129, 147-149). Together, these results indicate that CysLTs may serve as chemotactic ligands and activating mediators for human effector leukocytes. In the chronic asthma model, treatment with montelukast significantly reduced eosinophil infiltration, mucus plugging, and smooth muscle hyperplasia, demonstrating that CysLTs, particularly the CysLT pathway, initiate features of chronic inflammation (150). Furthermore, several CysLT 1 antagonists decreased LTD $_{4}$-induced chemotaxis of peripheral blood eosinophils from humans, rats, guinea pigs, and cynomolgus monkeys (148, 151-153). In contrast, in the OVA-induced asthma model, the level of LTC 4 in the BALF of challenged mice increased compared with those of the saline controls (154). These increases are correlated with an influx of predominantly eosinophils in airway tissues and BALF, suggesting the contribution of CysLT 2 in OVA-induced airway inflammation. A recent study further demonstrated that intranasal administration of $\mathrm{LTC}_{4}$ to OVA-sensitized mice induces airway eosinophilia via a platelet- and $\mathrm{CysLT}_{2}$-dependent pathway (155).

Microvascular permeability. CysLTs increase microvascular permeability in hamster cheek pouches (127) and guinea pig airways by promoting the contraction of endothelial cells, leading to gaps in the endothelium of venules (156-159). The latter effect is inhibited by pranlukast $(156,158)$, indicating the involvement

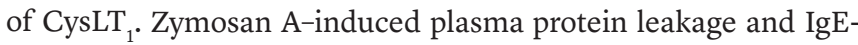
dependent passive cutaneous anaphylaxis are reduced in both CysLT - KO mice and LTC $_{4}$ synthase-KO mice (160). These results indicate the pivotal role of CysLT 1 in mediating increased vascular permeability in the models of both innate and adaptive immunity. However, several controversial data have been reported. For example, neutrophil recruitment is not impaired in either LTC $_{4}$ synthase-KO or CysLT $-\mathrm{KO}$ mice in the zymosan A-induced peritonitis model $(160,161)$. Moreover, the enhanced vascular permeability associated with the IgE-dependent passive cutaneous anaphylaxis is decreased in CysLT $-\mathrm{KO}$ mice, although the zymosan A- induced peritoneal inflammation is not altered (162). CysLT ${ }_{2}$ mediated vascular permeability via transendothelial vesicle transport was further investigated in a CysLT $\mathrm{T}_{2}-\mathrm{KO}$ LacZ mouse model (163). In this model, CysLT ${ }_{2}$ mediated inflammatory reactions in a vascular bed-specific manner by altering transendothelial vesicle transport-based vascular permeability. Further reports corroborate CysLT/CysLT 2 -induced permeability of human vascular endothelial cells (164).

Pulmonary fibrosis. Bleomycin (165), an anticancer agent, causes chronic pulmonary inflammation and fibrosis by intratracheal or systemic administration in mice. The induced injuries, e.g., pulmonary macrophage and neutrophil recruitment, fibroblast accumulation, and collagen deposition, are significantly reduced in $\mathrm{LTC}_{4}$ synthase-KO mice (166). Although these injuries are not prevented by CysLT ${ }_{1}$ deficiency in mice, CysLT $-\mathrm{KO}$ mice do show exaggerated alveolar septal thickening with reticular fiber deposition when compared with WT or LTC $_{4}$ synthase-KO mice (166). Additionally, CysLT levels in the BALF recovered from $\mathrm{CysLT}_{1}-\mathrm{KO}$ mice are greater than those of WT mice. These findings suggest that the CysLTs are crucial for bleomycin-induced chronic inflammatory and fibrotic insult, presumably working via other types of receptors, including $\mathrm{CysLT}_{2}$. Intriguingly, alveolar septal thickening after intratracheal injection of bleomycin is significantly reduced in CysLT 2 -KO mice (166). Because the amount of CysLTs in BALF is similar in CysLT $\mathrm{T}_{2}-\mathrm{KO}$ mice and WT mice, $\mathrm{CysLT}_{2}$ promotes chronic pulmonary inflammation with fibrosis in response to a particular pathological stimulus.

Cardiovascular effects. After reports of the reduced coronary blood flow induced by slow-reacting substance of anaphylaxis (SRS-A) (167), several groups have investigated the cardiovascular effects of CysLTs in several animal models. In sheep and pigs, CysLTs cause induction of coronary vasoconstriction and ischemia and impairment of left ventricular function $(168,169)$. Moreover, in isolated perfused guinea pig heart preparations, LTC $_{4}$ and $\mathrm{LTD}_{4}$ reduce myocardial contractility concomitant with the vasoconstriction $(170,171)$. In human heart, the negative inotropic effect of CysLTs is similar to that in guinea pigs, with rank order of potency $\mathrm{LTD}_{4}>\mathrm{LTC}_{4}>\mathrm{LTE}_{4}(172)$.

Although CysLT $_{2}$ is predominantly expressed in vascular smooth muscle cells, the expression of CysLT $\mathrm{T}_{1}$ is also induced by stimulation with lipopolysaccharide in human coronary artery vascular smooth muscle cells (173). Intriguingly, in these cells, CysLT is localized in the perinuclear region of human aortic valve myofibroblasts, and its activation is coupled to a predominantly nuclear $\mathrm{Ca}^{2+}$ signaling $(173,174)$. Furthermore, a recent report suggested that CysLTs elicit inflammation and proliferation of endothelial cells through CysLT ${ }_{2}$ and CysLT ${ }_{1}$, respectively (175). In this study, the authors further demonstrated that CysLT $_{2}$ activation leads to endothelial cell contraction and barrier disruption via the Rho kinase pathway, suggesting the critical roles of CysLT receptors in the pathology of cardiovascular diseases such as atherosclerosis.

\section{Clinical studies on CysLT receptor-targeted therapy}

CysLT receptors play an important role in the pathogenesis of bronchial asthma and allergic rhinitis. The effects of blockers of these receptors indicate that interventions in the signaling path- 
way via CysLT receptors may be of therapeutic use in the treatment of these diseases. Blockers of CysLT ${ }_{1}$, including montelukast (marketed as Singulair and Kipres), pranlukast (Onon), and zafirlukast (Accolate), are used in asthma and rhinitis. Montelukast, which is administered orally once daily, is the most prescribed antagonist for asthmatic patients (176). This drug is effective in allergic rhinitis and several types of asthma, e.g., exerciseinduced asthma, asthma in obese patients, asthma in smokers, and aspirin-induced asthma $(176,177)$. The beneficial effect of montelukast in cardiovascular disease has been under clinical trial (178-180). Pranlukast is an orally administered, selective, and competitive antagonist. Clinical studies demonstrated that prophylactic treatment with this drug is effective for chronic bronchial asthma in pediatric and adult patients. Moreover, recent studies suggested that pretreatment with this drug significantly inhibits pollinosis (181) and decreases nasal eosinophil cationic protein and obstruction (182). Zafirlukast is approved for treatment of asthma in patients 7 years or older. The most common adverse effects are pharyngitis, headache, rhinitis, and gastritis. Transient increases in liver enzymes and rare but significant liver dysfunction have prompted recommendations against prescribing this drug to patients with hepatic dysfunction (183).

\section{Conclusion}

CysLT $_{1}$ antagonists and inhibitors of LT biosynthesis are clinically useful to ameliorate the symptoms of bronchial asthma and allergic rhinitis. Although the past clinical studies on $\mathrm{BLT}_{1}$ antagonists failed to attenuate arthritis and psoriasis, studies using $\mathrm{BLT}_{1}-\mathrm{KO}$ mice and $\mathrm{BLT}_{1}$ antagonists are expanding the $\mathrm{BLT}_{1}$-related inflammatory diseases, suggesting the usefulness of $\mathrm{BLT}_{1}$ antagonists in the future. $\mathrm{BLT}_{2}$ agonists will target intractable skin and corneal ulcers, including bedsores. Thus, leukotriene receptors are still important drug targets.

\section{Acknowledgments}

This work is supported by Ministry of Education, Culture, Sports, Science and Technology (MEXT)/Japan Society for the Promotion of Science KAKENHI Grants 15H04708, 15H05897, and $18 \mathrm{HO} 2627$ (to TY), 17K082 (to MN), and S29229003 (to TS); AMED GAPFREE Program 17ak0101043h0003 (to TS); the Takeda Science Foundation (to TY, MN, and TS); the Naito Foundation (to MN); the Mitsubishi Foundation (to MN); a Grant-in-Aid (S1311011) from the Foundation of Strategic Research Projects in Private Universities from MEXT; and a grant from the Institute for Environmental and Gender-Specific Medicine (to TY). The laboratory at the University of Tokyo is funded by Shimadzu Co. Ltd., Japan, and the laboratory at the National Center for Global Health and Medicine is partially supported by ONO Pharmaceutical Co. We are grateful to T. Hori at Riken for generously drawing Figure 1.

Address correspondence to: Takehiko Yokomizo, Department of Biochemistry, Graduate School of Medicine, Juntendo University, Hongo 2-1-1, Bunkyo-ku, Tokyo 113-8421, Japan. Phone: 81.3.5802.1031; Email: yokomizo-tky@umin.ac.jp.
1. Shimizu T. Lipid mediators in health and disease: enzymes and receptors as therapeutic targets for the regulation of immunity and inflammation. Annu Rev Pharmacol Toxicol. 2009;49:123-150.

2. Saino $\mathrm{H}$, et al. The catalytic architecture of leukotriene $\mathrm{C} 4$ synthase with two arginine residues. J Biol Chem. 2011;286(18):16392-16401.

3. Rinaldo-Matthis A, et al. Arginine 104 is a key catalytic residue in leukotriene $\mathrm{C} 4$ synthase. J Biol Chem. 2010;285(52):40771-40776.

4. Martinez Molina D, et al. Structural basis for synthesis of inflammatory mediators by human leukotriene C4 synthase. Nature. 2007;448(7153):613-616.

5 . Ago H, et al. Crystal structure of a human membrane protein involved in cysteinyl leukotriene biosynthesis. Nature. 2007;448(7153):609-612.

6. Thunnissen MM, Nordlund P, Haeggström JZ. Crystal structure of human leukotriene A(4) hydrolase, a bifunctional enzyme in inflammation. Nat Struct Biol. 2001;8(2):131-135.

7. Nakamura M, Shimizu T. Leukotriene receptors. Chem Rev. 2011;111(10):6231-6298.

8. Yokomizo T, Izumi T, Chang K, Takuwa Y, Shimizu T. A G-protein-coupled receptor for leukotriene B4 that mediates chemotaxis. Nature. 1997;387(6633):620-624.

9. Yokomizo T, Kato K, Terawaki K, Izumi T, Shimizu T. A second leukotriene $\mathrm{B}(4)$ receptor, BLT2. A new therapeutic target in inflammation and immunological disorders. JExp Med. 2000;192(3):421-432.

10. Haribabu B. Back to the future of targeting leukotriene B4mediated inflammation. Semin
Immunol. 2017;33:1-2.

11. Wan M, Tang X, Stsiapanava A, Haeggström JZ. Biosynthesis of leukotriene B4. Semin Immunol. 2017;33:3-15.

12. Subramanian BC, Majumdar R, Parent CA. The role of the LTB4-BLT1 axis in chemotactic gradient sensing and directed leukocyte migration. Semin Immunol. 2017;33:16-29.

13. Saeki K, Yokomizo T. Identification, signaling, and functions of LTB4receptors. Semin Immunol. 2017;33:30-36.

14. Brandt SL, Serezani CH. Too much of a good thing: how modulating LTB4 actions restore host defense in homeostasis or disease. Semin Immunol. 2017;33:37-43.

15. Gelfand EW. Importance of the leukotriene B4-BLT1 and LTB4-BLT2 pathways in asthma. Semin Immunol. 2017;33:44-51.

16. Miyabe Y, Miyabe C, Luster AD. LTB4and BLT1 in inflammatory arthritis. Semin Immunol. 2017;33:52-57.

17. Jala VR, Bodduluri SR, Satpathy SR, Chheda Z, Sharma RK, Haribabu B. The yin and yang of leukotriene B4-mediated inflammation in cancer. Semin Immunol. 2017;33:58-64.

18. Bhatt L, Roinestad K, Van T, Springman EB. Recent advances in clinical development of leukotriene B4 pathway drugs. Semin Immunol. 2017;33:65-73.

19. Haribabu B, Verghese MW, Steeber DA, Sellars DD, Bock CB, Snyderman R. Targeted disruption of the leukotriene $\mathrm{B}(4)$ receptor in mice reveals its role in inflammation and platelet-activating factor-induced anaphylaxis. J Exp Med.
2000;192(3):433-438.

20. Tager AM, Dufour JH, Goodarzi K, Bercury SD, von Andrian UH, Luster AD. BLTR mediates leukotriene $\mathrm{B}(4)$-induced chemotaxis and adhesion and plays a dominant role in eosinophil accumulation in a murine model of peritonitis. J Exp Med. 2000;192(3):439-446.

21. Goodarzi K, Goodarzi M, Tager AM, Luster $\mathrm{AD}$, von Andrian UH. Leukotriene B4 and BLT1 control cytotoxic effector T cell recruitment to inflamed tissues. Nat Immunol. 2003;4(10):965-973

22. Ott VL, Cambier JC, Kappler J, Marrack P, Swanson BJ. Mast cell-dependent migration of effector $\mathrm{CD}^{+} \mathrm{T}$ cells through production of leukotriene B4. Nat Immunol. 2003;4(10):974-981.

23. Tager AM, et al. Leukotriene B4 receptor BLT1 mediates early effector T cell recruitment. Nat Immunol. 2003;4(10):982-990.

24. Miyahara N, et al. Leukotriene B4 receptor 1 expression on dendritic cells is required for the development of Th2 responses and allergeninduced airway hyperresponsiveness. J Immunol. 2008;181(2):1170-1178.

25. Toda A, Terawaki K, Yamazaki S, Saeki K, Shimizu T, Yokomizo T. Attenuated Th1 induction by dendritic cells from mice deficient in the leukotriene $\mathrm{B} 4$ receptor 1. Biochimie. 2010;92(6):682-691.

26. Serezani CH, Lewis C, Jancar S, Peters-Golden M. Leukotriene B4 amplifies NF- $\kappa$ B activation in mouse macrophages by reducing SOCS1 inhibition of MyD88 expression. J Clin Invest. 2011;121(2):671-682 
27. Heller EA, et al. Inhibition of atherogenesis in BLT1-deficient mice reveals a role for LTB4 and BLT1 in smooth muscle cell recruitment. Circulation. 2005;112(4):578-586.

28. Bäck M, Bu DX, Bränström R, Sheikine Y, Yan ZQ, Hansson GK. Leukotriene B4 signaling through NF-кB-dependent BLT1 receptors on vascular smooth muscle cells in atherosclerosis and intimal hyperplasia. Proc Natl Acad Sci U S A. 2005;102(48):17501-17506

29. Kuniyeda K, Okuno T, Terawaki K, Miyano M Yokomizo T, Shimizu T. Identification of the intracellular region of the leukotriene $\mathrm{B} 4$ receptor type 1 that is specifically involved in Gi activation. J Biol Chem. 2007;282(6):3998-4006.

30. Okuno T, Ago H, Terawaki K, Miyano M, Shimizu T, Yokomizo T. Helix 8 of the leukotriene B4 receptor is required for the conformational change to the low affinity state after G-protein activation. J Biol Chem. 2003;278(42):41500-41509.

31. Okuno T, Yokomizo T, Hori T, Miyano M, Shimizu T. Leukotriene B4 receptor and the function of its helix 8. J Biol Chem. 2005;280(37):32049-32052.

32. Chen Z, Gaudreau R, Le Gouill C, Rola-Pleszczynski M, Stanková J. Agonistinduced internalization of leukotriene $\mathrm{B}(4)$ receptor 1 requires G-protein-coupled receptor kinase 2 but not arrestins. Mol Pharmacol. 2004;66(3):377-386.

33. Gaudreau R, et al. Structural determinants regulating expression of the high affinity leukotriene B4 receptor: involvement of dileucine motifs and alpha-helix VIII. J Biol Chem. 2004;279(11):10338-10345.

34. Aratake Y, et al. Helix 8 of leukotriene B4 receptor 1 inhibits ligand-induced internalization. FASEB J. 2012;26(10):4068-4078.

35. Hori $\mathrm{T}$, et al. $\mathrm{Na}^{+}$-mimicking ligands stabilize the inactive state of leukotriene B4receptor BLT1. Nat Chem Biol. 2018;14(3):262-269.

36. Basu S, et al. Critical role for polar residues in coupling leukotriene B4 binding to signal transduction in BLT1. J Biol Chem. 2007;282(13):10005-10017.

37. Terawaki K, et al. Absence of leukotriene B4 receptor 1 confers resistance to airway hyperresponsiveness and Th2-type immune responses. J Immunol. 2005;175(7):4217-4225.

38. Okamoto F, Saeki K, Sumimoto H, Yamasaki S, Yokomizo T. Leukotriene B4 augments and restores Fc $\gamma$ Rs-dependent phagocytosis in macrophages. J Biol Chem. 2010;285(52):41113-41121.

39. Ichiki T, et al. Modulation of leukotriene B4 receptor 1 signaling by receptor for advanced glycation end products (RAGE). FASEB J. 2016;30(5):1811-1822.

40. Ichiki T, Koga T, Yokomizo T. Receptor for advanced glycation end products regulates leukotriene B4 receptor 1 signaling. DNA Cell Biol. 2016;35(12):747-750.

41. Kato K, Yokomizo T, Izumi T, Shimizu T. Cell-specific transcriptional regulation of human leukotriene $\mathrm{B}(4)$ receptor gene. J Exp Med. 2000;192(3):413-420.

42. Kamohara M, et al. Molecular cloning and characterization of another leukotriene $\mathrm{B} 4$ receptor. J Biol Chem. 2000;275(35):27000-27004.

43. Tryselius Y, Nilsson NE, Kotarsky K, Olde B,
Owman C. Cloning and characterization of cDNA encoding a novel human leukotriene $\mathrm{B}(4)$ receptor. Biochem Biophys Res Commun. 2000;274(2):377-382.

44. Wang S, et al. A novel hepatointestinal leukotriene $\mathrm{B} 4$ receptor. Cloning and functional characterization. J Biol Chem. 2000;275(52):40686-40694.

45. Yokomizo T, Kato K, Hagiya H, Izumi T, Shimizu T. Hydroxyeicosanoids bind to and activate the low affinity leukotriene B4 receptor, BLT2. J Biol Chem. 2001;276(15):12454-12459.

46. Okuno T, Iizuka Y, Okazaki H, Yokomizo T, Taguchi R, Shimizu T. 12(S)-Hydroxyheptadeca-5Z, 8E, 10E-trienoic acid is a natural ligand for leukotriene B4 receptor 2. J Exp Med. 2008;205(4):759-766.

47. Hecker M, Haurand M, Ullrich V, Diczfalusy U, Hammarström S. Products, kinetics, and substrate specificity of homogeneous thromboxane synthase from human platelets: development of a novel enzyme assay. Arch Biochem Biophys. 1987;254(1):124-135.

48. Hecker M, Ullrich V. On the mechanism of prostacyclin and thromboxane A2 biosynthesis. J Biol Chem. 1989;264(1):141-150.

49. Hamberg M, Samuelsson B. Oxygenation of unsaturated fatty acids by the vesicular gland of sheep. J Biol Chem. 1967;242(22):5344-5354.

50. Matsunobu T, Okuno T, Yokoyama C, Yokomizo T. Thromboxane A synthase-independent production of 12-hydroxyheptadecatrienoic acid, a BLT2 ligand. J Lipid Res. 2013;54(11):2979-2987.

51. Lee JW, Kim JH. Activation of the leukotriene B4 receptor 2-reactive oxygen species (BLT2-ROS) cascade following detachment confers anoikis resistance in prostate cancer cells. J Biol Chem. 2013;288(42):30054-30063.

52. Iizuka Y, Yokomizo T, Terawaki K, Komine M, Tamaki K, Shimizu T. Characterization of a mouse second leukotriene $\mathrm{B} 4$ receptor, $\mathrm{mBLT} 2$ : BLT2-dependent ERK activation and cell migration of primary mouse keratinocytes. J Biol Chem. 2005;280(26):24816-24823.

53. Liu M, et al. 12-Hydroxyheptadecatrienoic acid promotes epidermal wound healing by accelerating keratinocyte migration via the BLT2 receptor. J Exp Med. 2014;211(6):1063-1078.

54. Iwamoto S, et al. Non-steroidal anti-inflammatory drug delays corneal wound healing by reducing production of 12-hydroxyheptadecatrienoic acid, a ligand for leukotriene B4 receptor 2. Sci Rep. 2017;7(1):13267.

55. Iizuka Y, et al. Protective role of the leukotriene $\mathrm{B} 4$ receptor BLT2 in murine inflammatory colitis. FASEB J. 2010;24(12):4678-4690.

56. Shigematsu M, et al. Leukotriene B4 receptor type 2 protects against pneumolysin-dependent acute lung injury. Sci Rep. 2016;6:34560.

57. Bäck M, et al. International Union of Basic and Clinical Pharmacology. LXXXIV: leukotriene receptor nomenclature, distribution, and pathophysiological functions. Pharmacol Rev. 2011;63(3):539-584.

58. Patnode ML, Bando JK, Krummel MF, Locksley RM, Rosen SD. Leukotriene B4 amplifies eosinophil accumulation in response to nematodes. J Exp Med. 2014;211(7):1281-1288.

59. Chen $\mathrm{H}$, et al. Effects of leukotriene B4 and prostaglandin E2 on the differentiation of murine Foxp $3^{+}$T regulatory cells and Th17 cells. Prostaglandins Leukot Essent Fatty Acids. 2009;80(4):195-200.

60. Pettersson A, Richter J, Owman C. Flow cytometric mapping of the leukotriene B4 receptor, BLT1, in human bone marrow and peripheral blood using specific monoclonal antibodies. Int Immunopharmacol. 2003;3(10-11):1467-1475.

61. Sasaki F, et al. Biochemical and immunological characterization of a novel monoclonal antibody against mouse leukotriene B4 receptor 1. PLoS One. 2017;12(9):e0185133.

62. Miyahara N, et al. Requirement for leukotriene $\mathrm{B} 4$ receptor 1 in allergen-induced airway hyperresponsiveness. Am J Respir Crit Care Med. 2005;172(2):161-167.

63. Miyahara N, et al. Leukotriene B4 receptor-1 is essential for allergen-mediated recruitment of $\mathrm{CD}^{+} \mathrm{T}$ cells and airway hyperresponsiveness. JImmunol. 2005;174(8):4979-4984.

64. Kim ND, Chou RC, Seung E, Tager AM, Luster $\mathrm{AD}$. A unique requirement for the leukotriene B4 receptor BLT1 for neutrophil recruitment in inflammatory arthritis. J Exp Med 2006;203(4):829-835.

65. Miyabe Y, et al. Complement C5a receptor is the key initiator of neutrophil adhesion igniting immune complex-induced arthritis. Sci Immunol. 2017;2(7):eaaj2195.

66. Chen M, et al. Neutrophil-derived leukotriene B4 is required for inflammatory arthritis. J Exp Med. 2006;203(4):837-842.

67. Shao WH, Del Prete A, Bock CB, Haribabu B. Targeted disruption of leukotriene $\mathrm{B} 4$ receptors BLT1 and BLT2: a critical role for BLT1 in collagen-induced arthritis in mice. J Immunol. 2006;176(10):6254-6261.

68. Griffiths RJ, et al. Leukotriene B4 plays a critical role in the progression of collagen-induced arthritis. Proc Natl Acad Sci U S A. 1995;92(2):517-521.

69. Friedrich EB, et al. Mechanisms of leukotriene B4 - triggered monocyte adhesion. Arterioscler Thromb Vasc Biol. 2003;23(10):1761-1767.

70. Huang L, et al. Leukotriene B4 strongly increases monocyte chemoattractant protein-1 in human monocytes. Arterioscler Thromb Vasc Biol. 2004;24(10):1783-1788.

71. Aiello RJ, Bourassa PA, Lindsey S, Weng W, Freeman A, Showell HJ. Leukotriene B4 receptor antagonism reduces monocytic foam cells in mice. Arterioscler Thromb Vasc Biol. 2002;22(3):443-449.

72. Subbarao K, et al. Role of leukotriene B4 receptors in the development of atherosclerosis: potential mechanisms. Arterioscler Thromb Vasc Biol. 2004;24(2):369-375.

73. Wang D, Dubois RN. Eicosanoids and cancer. Nat Rev Cancer. 2010;10(3):181-193.

74. Sharma-Walia N, Chandran K, Patel K, Veettil MV, Marginean A. The Kaposi's sarcoma-asso ciated herpesvirus (KSHV)-induced 5-lipoxygenase-leukotriene $\mathrm{B} 4$ cascade plays key roles in KSHV latency, monocyte recruitment, and lipogenesis. J Virol. 2014;88(4):2131-2156.

75. Wen Z, et al. Increased metabolites of 5-lipoxygenase from hypoxic ovarian cancer cells promote tumor-associated macrophage infiltration. 
Oncogene. 2015;34(10):1241-1252.

76. Gounaris E, et al. Zileuton, 5-lipoxygenase inhibitor, acts as a chemopreventive agent in intestinal polyposis, by modulating polyp and systemic inflammation. PLoS One. 2015;10(3):e0121402.

77. Jala VR, et al. Leukotriene B4-receptor-1 mediated host response shapes gut microbiota and controls colon tumor progression. Oncoimmunology. 2017;6(12):e1361593.

78. Marder P, et al. Inhibition of ex vivo neutrophil activation by oral LY293111, a novel leukotriene B4 receptor antagonist. Br J Clin Pharmacol. 1996;42(4):457-464.

79. van Pelt JP, et al. The regulation of CD11b integrin levels on human blood leukocytes and leukotriene B4-stimulated skin by a specific leukotriene B4 receptor antagonist (LY293111). Biochem Pharmacol. 1997;53(7):1005-1012.

80. Evans DJ, Barnes PJ, Spaethe SM, van Alstyne EL, Mitchell MI, O'Connor BJ. Effect of a leukotriene B4 receptor antagonist, LY293111, on allergen induced responses in asthma. Thorax. 1996;51(12):1178-1184.

81. Sumida $\mathrm{H}$, et al. Interplay between CXCR2 and BLT1 facilitates neutrophil infiltration and resultant keratinocyte activation in a murine model of imiquimod-induced psoriasis. J Immunol. 2014;192(9):4361-4369.

82. Van Pelt JP, et al. Investigation on a novel and specific leukotriene $\mathrm{B} 4$ receptor antagonist in the treatment of stable plaque psoriasis. Br J Dermatol.1998;139(3):396-402.

83. Mommers JM, Van Rossum MM, KooijmansOtero ME, Parker GL, van de Kerkhof PC. VML 295 (LY-293111), a novel LTB4 antagonist, is not effective in the prevention of relapse in psoriasis. Br J Dermatol. 2000;142(2):259-266.

84. Schmitt-Grohé S, Zielen S. Leukotriene receptor antagonists in children with cystic fibrosis lung disease: anti-inflammatory and clinical effects. Paediatr Drugs. 2005;7(6):353-363.

85. Ding XZ, Talamonti MS, Bell RH Jr, Adrian TE. A novel anti-pancreatic cancer agent, LY293111. Anticancer Drugs. 2005;16(5):467-473.

86. Schwartz GK, et al. Phase I and pharmacokinetic study of LY293111, an orally bioavailable LTB4 receptor antagonist, in patients with advanced solid tumors. JClin Oncol. 2005;23(23):5365-5373.

87. Luo L, et al. A synthetic leukotriene B4 receptor type 2 agonist accelerates the cutaneous wound healing process in diabetic rats by indirect stimulation of fibroblasts and direct stimulation of keratinocytes. J Diabetes Complicat. 2017;31(1):13-20.

88. Ishii $\mathrm{Y}$, et al. Leukotriene $\mathrm{B} 4$ receptor type 2 (BLT2) enhances skin barrier function by regulating tight junction proteins. FASEB J. 2016;30(2):933-947.

89. Matsunaga Y, et al. Leukotriene B4 receptor BLT2 negatively regulates allergic airway eosinophilia. FASEB J. 2013;27(8):3306-3314.

90. Lynch KR, et al. Characterization of the human cysteinyl leukotriene CysLT1 receptor. Nature. 1999;399(6738):789-793.

91. Sarau HM, et al. Identification, molecular cloning, expression, and characterization of a cysteinyl leukotriene receptor. Mol Pharmacol. 1999;56(3):657-663.
92. Woszczek G, et al. Functional characterization of human cysteinyl leukotriene 1 receptor gene structure. J Immunol. 2005;175(8):5152-5159.

93. Heise CE, et al. Characterization of the human cysteinyl leukotriene 2 receptor. J Biol Chem. 2000;275(39):30531-30536.

94. Takasaki J, et al. The molecular characterization and tissue distribution of the human cysteinyl leukotriene CysLT(2) receptor. Biochem Biophys Res Commun. 2000;274(2):316-322.

95. Nothacker HP, Wang Z, Zhu Y, Reinscheid RK, Lin SH, Civelli O. Molecular cloning and characterization of a second human cysteinyl leukotriene receptor: discovery of a subtype selective agonist. Mol Pharmacol. 2000;58(6):1601-1608.

96. Kanaoka Y, Boyce JA. Cysteinyl leukotrienes and their receptors: cellular distribution and function in immune and inflammatory responses. JImmunol. 2004;173(3):1503-1510.

97. Paruchuri S, et al. Leukotriene E4-induced pulmonary inflammation is mediated by the P2Y12 receptor. JExp Med. 2009;206(11):2543-2555.

98. Fumagalli M, et al. Phenotypic changes, signaling pathway, and functional correlates of GPR17-expressing neural precursor cells during oligodendrocyte differentiation. J Biol Chem. 2011;286(12):10593-10604.

99. Kanaoka Y, Maekawa A, Austen KF. Identification of GPR99 protein as a potential third cysteinyl leukotriene receptor with a preference for leukotriene E4 ligand. J Biol Chem. 2013;288(16):10967-10972.

100.Figueroa DJ, et al. Expression of the cysteinyl leukotriene 1 receptor in normal human lung and peripheral blood leukocytes. Am J Respir Crit Care Med. 2001;163(1):226-233.

101.Zhu J, et al. Localization and upregulation of cysteinyl leukotriene-1 receptor in asthmatic bronchial mucosa. Am J Respir Cell Mol Biol. 2005;33(6):531-540.

102. Frey EA, Nicholson DW, Metters KM. Characterization of the leukotriene $\mathrm{D} 4$ receptor in dimethylsulphoxide-differentiated U937 cells: comparison with the leukotriene $\mathrm{D} 4$ receptor in human lung and guinea-pig lung. Eur J Pharmacol. 1993;244(3):239-250.

103. Crooke ST, et al. The signal transduction system of the leukotriene D4 receptor. Trends Pharmacol Sci. 1989;10(3):103-107.

104.Watanabe T, et al. Characterization of the guinea pig lung membrane leukotriene D4 receptor solubilized in an active form. Association and dissociation with an islet-activating protein-sensitive guanine nucleotide-binding protein. J Biol Chem. 1990;265(34):21237-21241.

105. Baud L, Goetzl EJ, Koo CH. Stimulation by leukotriene D4 of increases in the cytosolic concentration of calcium in dimethylsulfoxide-differentiated HL-60 cells. JClin Invest. 1987;80(4):983-991.

106.Pollock K, Creba J. Leukotriene D4 induced calcium changes in U937 cells may utilize mechanisms additional to inositol phosphate production that are pertussis toxin insensitive but are blocked by phorbol myristate acetate. Cell Signal. 1990;2(6):563-568.

107. Capra V, et al. Involvement of prenylated proteins in calcium signaling induced by LTD 4 in differ- entiated U937 cells. Prostaglandins Other Lipid Mediat. 2003;71(3-4):235-251.

108. Adolfsson JL, Ohd JF, Sjölander A. Leukotriene D4-induced activation and translocation of the G-protein ai3-subunit in human epithelial cells. Biochem Biophys Res Commun. 1996;226(2):413-419.

109. James AJ, Sampson AP. A tale of two CysLTs. Clin Exp Allergy. 2001;31(11):1660-1664.

110. Kamohara M, et al. Functional characterization of cysteinyl leukotriene CysLT(2) receptor on human coronary artery smooth muscle cells. Biochem Biophys Res Commun. 2001;287(5):1088-1092.

111. Labat $\mathrm{C}$, et al. A second cysteinyl leukotriene receptor in human lung. J Pharmacol Exp Ther. 1992;263(2):800-805.

112. Tudhope SR, et al. BAY u9773, a novel antagonist of cysteinyl-leukotrienes with activity against two receptor subtypes. Eur J Pharmacol. 1994;264(3):317-323.

113. Mellor EA, et al. Expression of the type 2 receptor for cysteinyl leukotrienes (CysLT2R) by human mast cells: functional distinction from CysLT1R. Proc Natl Acad Sci U S A. 2003;100(20):11589-11593.

114. Barrett NA, et al. Cysteinyl leukotriene 2 receptor on dendritic cells negatively regulates liganddependent allergic pulmonary inflammation. JImmunol. 2012;189(9):4556-4565.

115. Cummings HE, et al. Cutting edge: Leukotriene $\mathrm{C} 4$ activates mouse platelets in plasma exclusively through the type 2 cysteinyl leukotriene receptor. JImmunol. 2013;191(12):5807-5810.

116. Paruchuri S, Jiang Y, Feng C, Francis SA, Plutzky $\mathrm{J}$, Boyce JA. Leukotriene $\mathrm{E} 4$ activates peroxisome proliferator-activated receptor gamma and induces prostaglandin D2 generation by human mast cells. J Biol Chem. 2008;283(24):16477-16487.

117. Suh DH, et al. P2Y12 antagonist attenuates eosinophilic inflammation and airway hyperresponsiveness in a mouse model of asthma. J Cell Mol Med. 2016;20(2):333-341.

118. He W, et al. Citric acid cycle intermediates as ligands for orphan G-protein-coupled receptors. Nature. 2004;429(6988):188-193.

119. Wittenberger T, Hellebrand S, Munck A, Kreienkamp HJ, Schaller HC, Hampe W. GPR99, a new $G$ protein-coupled receptor with homology to a new subgroup of nucleotide receptors. $B M C$ Genomics. 2002;3:17.

120. Inbe H, Watanabe S, Miyawaki M, Tanabe E, Encinas JA. Identification and characterization of a cell-surface receptor, P2Y15, for AMP and adenosine. J Biol Chem. 2004;279(19):19790-19799.

121. Bankova LG, et al. Leukotriene $\mathrm{E} 4$ elicits respiratory epithelial cell mucin release through the G-protein-coupled receptor, GPR99. Proc Natl Acad Sci U S A. 2016;113(22):6242-6247.

122. Ciana P, et al. The orphan receptor GPR17 identified as a new dual uracil nucleotides/ cysteinyl-leukotrienes receptor. $E M B O J$. 2006;25(19):4615-4627.

123. Marschallinger J, et al. Structural and functional rejuvenation of the aged brain by an approved anti-asthmatic drug. Nat Commun. 2015;6:8466.

124.Fumagalli M, Lecca D, Coppolino GT, Parravicini C, Abbracchio MP. Pharmacological properties and biological functions of the GPR17 receptor, a potential target for neuro-regenerative medicine. 
Adv Exp Med Biol. 2017;1051:169-192.

125. Maekawa A, Balestrieri B, Austen KF, Kanaoka Y. GPR17 is a negative regulator of the cysteinyl leukotriene 1 receptor response to leukotriene D4. Proc Natl Acad Sci U S A. 2009;106(28):11685-11690.

126. Maekawa A, Xing W, Austen KF, Kanaoka Y. GPR17 regulates immune pulmonary inflammation induced by house dust mites. J Immunol. 2010;185(3):1846-1854.

127. Dahlén SE, et al. Leukotrienes promote plasma leakage and leukocyte adhesion in postcapillary venules: in vivo effects with relevance to the acute inflammatory response. Proc Natl Acad Sci US A. 1981;78(6):3887-3891.

128. Coles SJ, et al. Effects of leukotrienes C4 and D4 on glycoprotein and lysozyme secretion by human bronchial mucosa. Prostaglandins. 1983;25(2):155-170.

129. Laitinen LA, Laitinen A, Haahtela T, Vilkka V, Spur BW, Lee TH. Leukotriene E4 and granulocytic infiltration into asthmatic airways. Lancet. 1993;341(8851):989-990.

130. Panettieri RA, Tan EM, Ciocca V, Luttmann MA, Leonard TB, Hay DW. Effects of LTD4 on human airway smooth muscle cell proliferation, matrix expression, and contraction in vitro: differential sensitivity to cysteinyl leukotriene receptor antagonists. Am J Respir Cell Mol Biol. 1998;19(3):453-461.

131. Nicosia S, Capra V, Rovati GE. Leukotrienes as mediators of asthma. Pulm Pharmacol Ther. 2001;14(1):3-19.

132. Arm JP. Leukotriene generation and clinical implications. Allergy Asthma Proc. 2004;25(1):37-42.

133. Ravasi S, Citro S, Viviani B, Capra V, Rovati GE. CysLT1 receptor-induced human airway smooth muscle cells proliferation requires ROS generation, EGF receptor transactivation and ERK1/2 phosphorylation. Respir Res. 2006;7:42.

134. Drazen JM, et al. Comparative airway and vascular activities of leukotrienes C-1 and D in vivo and in vitro. Proc Natl Acad Sci US A. 1980;77(7):4354-4358.

135. Krell RD, Tsai BS, Berdoulay A, Barone M, Giles RE. Heterogeneity of leukotriene receptors in guinea-pig trachea. Prostaglandins. 1983;25(2):171-178.

136. Lee TH, Austen KF, Corey EJ, Drazen JM. Leukotriene E4-induced airway hyperresponsiveness of guinea pig tracheal smooth muscle to histamine and evidence for three separate sulfidopeptide leukotriene receptors. Proc Natl Acad Sci US A. 1984;81(15):4922-4925.

137. Davidson $\mathrm{AB}$, et al. Bronchoconstrictor effects of leukotriene $\mathrm{E} 4$ in normal and asthmatic subjects. Am Rev Respir Dis. 1987;135(2):333-337.

138. Drazen JM. Comparative contractile responses to sulfidopeptide leukotrienes in normal and asthmatic human subjects. Ann N Y Acad Sci. 1988;524:289-297.

139. Arm JP, et al. Asthmatic airways have a disproportionate hyperresponsiveness to LTE4, as compared with normal airways, but not to LTC4, LTD4, methacholine, and histamine. Am Rev Respir Dis. 1990;142(5):1112-1118.

140. Gauvreau GM, Parameswaran KN, Watson RM, O'Byrne PM. Inhaled leukotriene E(4), but not leukotriene $\mathrm{D}(4)$, increased airway inflammatory cells in subjects with atopic asthma. Am J Respir Crit Care Med. 2001;164(8 pt 1):1495-1500.

141. Yonetomi Y, et al. Leukotriene $\mathrm{C} 4$ induces bronchoconstriction and airway vascular hyperpermeability via the cysteinyl leukotriene receptor 2 in S-hexyl glutathione-treated guinea pigs. Eur J Pharmacol. 2015;754:98-104.

142. Yonetomi Y, et al. Effects of ONO-6950, a novel dual cysteinyl leukotriene 1 and 2 receptors antagonist, in a guinea pig model of asthma. Eur J Pharmacol. 2015;765:242-248.

143. Sekioka T, et al. Expression of CysLT2 receptors in asthma lung, and their possible role in bronchoconstriction. Allergol Int. 2015;64(4):351-358.

144.Zeidler MR, et al. Montelukast improves regional air-trapping due to small airways obstruction in asthma. Eur Respir J. 2006;27(2):307-315.

145. Sekioka T, et al. CysLT2receptor activation is involved in LTC4-induced lung air-trapping in guinea pigs. Eur J Pharmacol. 2017;794:147-153.

146. Mita H, Hasegawa M, Saito H, Akiyama K. Levels of cysteinyl leukotriene receptor mRNA in human peripheral leucocytes: significantly higher expression of cysteinyl leukotriene receptor 2 mRNA in eosinophils. Clin Exp Allergy. 2001;31(11):1714-1723.

147. Smith LJ, Shamsuddin M, Houston M. Effect of leukotriene D4 and platelet-activating factor on human alveolar macrophage eicosanoid and PAF synthesis. Am Rev Respir Dis. 1993;148(3):682-688.

148.Foster A, Chan CC. Peptide leukotriene involvement in pulmonary eosinophil migration upon antigen challenge in the actively sensitized guinea pig. Int Arch Allergy Appl Immunol. 1991;96(3):279-284.

149. Underwood DC, Osborn RR, Newsholme SJ, Torphy TJ, Hay DW. Persistent airway eosinophilia after leukotriene (LT) D4 administration in the guinea pig: modulation by the LTD4 receptor antagonist, pranlukast, or an interleukin-5 monoclonal antibody. Am J Respir Crit Care Med. 1996;154(4 pt 1):850-857.

150.Israel E, et al. Effects of montelukast and beclomethasone on airway function and asthma control. J Allergy Clin Immunol. 2002;110(6):847-854.

151. Spada CS, Nieves AL, Krauss AH, Woodward DF. Comparison of leukotriene B4 and D4 effects on human eosinophil and neutrophil motility in vitro. JLeukoc Biol. 1994;55(2):183-191.

152. Salmon M, et al. Involvement of cysteinyl leukotrienes in airway smooth muscle cell DNA synthesis after repeated allergen exposure in sensitized Brown Norway rats. Br J Pharmacol. 1999;127(5):1151-1158.

153. Turner CR, Smith WB, Andresen CJ, Swindell AC, Watson JW. Leukotriene D4 receptor antagonism reduces airway hyperresponsiveness in monkeys. Pulm Pharmacol. 1994;7(1):49-58.

154. Henderson WR Jr, et al. The importance of leukotrienes in airway inflammation in a mouse model of asthma. J Exp Med. 1996;184(4):1483-1494.

155. Liu T, et al. Platelet-driven leukotriene C4-mediated airway inflammation in mice is aspirin-sensitive and depends on $\mathrm{T}$ prostanoid receptors. J Immunol. 2015;194(11):5061-5068.

156. Nakagawa N, et al. In vivo pharmacologic profile of ONO-1078: a potent, selective and orally active peptide leukotriene (LT) antagonist. Jpn J Pharmacol. 1992;60(3):217-225.

157. Evans TW, Rogers DF, Aursudkij B, Chung KF, Barnes PJ. Regional and time-dependent effects of inflammatory mediators on airway microvascular permeability in the guinea pig. Clin Sci. 1989;76(5):479-485.

158. Bochnowicz S, Underwood DC. Dose-dependent mediation of leukotriene D4-induced airway microvascular leakage and bronchoconstriction in the guinea pig. Prostaglandins Leukot Essent Fatty Acids. 1995;52(6):403-411.

159. Joris I, Majno G, Corey EJ, Lewis RA. The mechanism of vascular leakage induced by leukotriene E4. Endothelial contraction. Am J Pathol. 1987;126(1):19-24.

160. Maekawa A, Austen KF, Kanaoka Y. Targeted gene disruption reveals the role of cysteinyl leukotriene 1 receptor in the enhanced vascular permeability of mice undergoing acute inflammatory responses. J Biol Chem. 2002;277(23):20820-20824.

161. Kanaoka Y, Maekawa A, Penrose JF, Austen KF, Lam BK. Attenuated zymosan-induced peritoneal vascular permeability and IgEdependent passive cutaneous anaphylaxis in mice lacking leukotriene C4 synthase. J Biol Chem. 2001;276(25):22608-22613.

162.Beller TC, Maekawa A, Friend DS, Austen KF, Kanaoka Y. Targeted gene disruption reveals the role of the cysteinyl leukotriene 2 receptor in increased vascular permeability and in bleomycin-induced pulmonary fibrosis in mice. J Biol Chem. 2004;279(44):46129-46134.

163. Moos MP, et al. Cysteinyl leukotriene 2 receptor-mediated vascular permeability via transendothelial vesicle transport. FASEB J. 2008;22(12):4352-4362.

164. Capra V, et al. Autocrine activity of cysteinyl leukotrienes in human vascular endothelial cells: signaling through the CysLT(2) receptor. Prostaglandins Other Lipid Mediat. 2015;120:115-125.

165. Umezawa H, Takeuchi T, Hori S, Sawa T, Ishizuka M. Studies on the mechanism of antitumor effect of bleomycin of squamous cell carcinoma. JAntibiot. 1972;25(7):409-420.

166. Beller TC, Friend DS, Maekawa A, Lam BK, Austen KF, Kanaoka Y. Cysteinyl leukotriene 1 receptor controls the severity of chronic pulmonary inflammation and fibrosis. Proc Natl Acad Sci US A. 2004;101(9):3047-3052.

167. Levi R, Burke JA. Cardiac anaphylaxis: SRS-A potentiates and extends the effects of released histamine. Eur J Pharmacol. 1980;62(1):41-49.

168. Michelassi F, et al. Leukotriene D4: a potent coronary artery vasoconstrictor associated with impaired ventricular contraction. Science. 1982;217(4562):841-843.

169. Fiedler VB, Mardin M, Gardiner PJ, Abram TS. Leukotrienes on porcine hemodynamics and prostanoid release. Int J Cardiol. 1985;8(4):451-463.

170.Letts LG, Newman DL, Greenwald SE, Piper PJ. Effects of intra-coronary administration of leukotriene D4 in the anaesthetized dog. Prostaglandins. 1983;26(4):563-572.

171. Roth DM, Lefer DJ, Hock CE, Lefer AM. Effects of peptide leukotrienes on cardiac dynamics in rat, cat, and guinea pig hearts. Am J Physiol. 
1985;249(3 pt 2):H477-H484.

172. Burke JA, Levi R, Guo ZG, Corey EJ. Leukotrienes C4, D4 and E4: effects on human and guinea-pig cardiac preparations in vitro.J Pharmacol Exp Ther. 1982;221(1):235-241.

173. Eaton A, Nagy E, Pacault M, Fauconnier J, Bäck M. Cysteinyl leukotriene signaling through perinuclear CysLT(1) receptors on vascular smooth muscle cells transduces nuclear calcium signaling and alterations of gene expression. J Mol Med. 2012;90(10):1223-1231.

174. Nagy E, et al. Upregulation of the 5-lipoxygenase pathway in human aortic valves correlates with severity of stenosis and leads to leukotrieneinduced effects on valvular myofibroblasts. Circulation. 2011;123(12):1316-1325.

175. Duah E, et al. Cysteinyl leukotrienes regulate endothelial cell inflammatory and proliferative signals through CysLT(2) and CysLT(1) receptors. Sci Rep. 2013;3:3274.

176. Marcello C, Carlo L. Asthma phenotypes: the intriguing selective intervention with Montelukast. Asthma Res Pract. 2016;2:11.

177. Pacheco Y, Freymond N, Devouassoux G. Impact of montelukast on asthma associated with rhinitis, and other triggers and co-morbidities. JAsthma. 2014;51(1):1-17.

178. Ingelsson E, Yin L, Back M. Nationwide cohort study of the leukotriene receptor antagonist montelukast and incident or recurrent cardiovascular disease. JAllergy Clin Immunol. 2012;129(3):702-707.e702.

179. Bäck M, et al. Update on leukotriene, lipoxin and oxoeicosanoid receptors: IUPHAR Review 7. $\mathrm{Br} \mathrm{J}$ Pharmacol. 2014;171(15):3551-3574.

180. Hoxha M, Rovati GE, Cavanillas AB. The leu- kotriene receptor antagonist montelukast and its possible role in the cardiovascular field. Eur $J$ Clin Pharmacol. 2017;73(7):799-809.

181. Gotoh M, Suzuki H, Okubo K. Delay of onset of symptoms of Japanese cedar pollinosis by treatment with a leukotriene receptor antagonist. Allergol Int. 2011;60(4):483-489.

182. Gotoh M, et al. Noninvasive biological evaluation of response to pranlukast treatment in pediatric patients with Japanese cedar pollinosis. Allergy Asthma Proc. 2012;33(6):459-466.

183. Scow DT, Luttermoser GK, Dickerson KS. Leukotriene inhibitors in the treatment of allergy and asthma. Am Fam Physician. 2007;75(1):65-70.

184. Morris GM, et al. AutoDock4 and AutoDockTools4: automated docking with selective receptor flexibility. J Comput Chem. 2009;30(16):2785-2791. 